\title{
ECLECTIC APPROACH TO THE CATEGORICAL IMPERATIVE AND PLEASURE
}

\author{
KowKwegyaAmissah Abraham* \\ http://dx.doi.org/10.4314/og.v14i1.2
}

\begin{abstract}
This work specifically looks at the concept of the categorical imperative as a pivotal principle in Kant's deontology and Mill's conception of pleasure. The focus is to examine potential opening for harmonisation. Thus we establish here, that the basic drivers for these principles are the same. This creates an opening for eclecticism even though the two conceptions are embedded in two theories that lie at the extreme opposites of the moral continuum. The motivation is that contemporary complex moral decision-making elicits an eclectic approach in normative assessment of theories to respond to praxeology in deciding on an action that has a moral content.
\end{abstract}

\section{Introduction}

The moral law, in Kant's thought is a kind of command that demands obedience. This is different from the normal commands we encounter in our daily lives, which are normally issued by a supreme being or other authorities. The moral law that Kant alludes to is promulgated by reason. This is not like any other imperative of which one has ever heard of, because it is not a means to the achievement of anything and it also has no relation to whatever anyone wants. It, thus, becomes a command which is absolute and as such has to be obeyed without any exception. Before proceeding with an in-depth explanation of the categorical imperative, we need to explain what Kant means by imperative and who qualifies to be a rational agent. A rational agent as explained by Paton (1964) is one who has the power to act in accordance with one's idea of laws or principles. This is what we mean when we say of a rational agent that he has a will. The actions of a rational agent have a subjective principle or maxim and objective principle. This objective principle is one on which a rational agent would necessarily act if his passion is controlled by reason. Actions based on these principles may be described as in some sense 'good'. We must, however, note Kant's observation that humans do not always act on objective principles, 
Kwo Kwegya: Eclectic Approach to the Categorical ...

the reason being that we are imperfect rational beings. For rational beings that are imperfect like humans, objective principles always necessitate the will. In cases when objective principles seem to necessitate the will, the principle may be described as a command, or an imperative. Kant (1959)in distinguishing between different kinds of imperatives observes that some imperatives are conditioned by a will for some particular ends. In this case, such an imperative would necessarily give rise to hypothetical imperatives. They bid us to do actions which are good as a means to an end that we might will.

However, some imperatives or objective principles are unconditional. Such principles would necessarily be followed by a rational agent without any desire for the attainment of some ulterior end. They may also be called 'apodeictic', that is, it is necessary in the sense of it being unconditioned and absolute (Kant, 1959). Hypothetical imperative is a conditional imperative which commands a person to do something as a means to an end (Kant, 1959). Thus, it is a command of reason that applies only if we desire the goal. For instance, statements like, "be honest, so that people will think well of you", "if you want to pass the course you ought to complete the assignment" are all examples of hypothetical imperatives. He further distinguishes between problematic hypothetical imperative and assertoric hypothetical imperatives(Kant, 1959). Example of problematic hypothetical imperatives is; "If you want to be a good philosopher you must study ethics". Assertoric hypothetical imperative, however, commands one to believe in certain ways in order to be happy (Omoregbe, 2004). Directly opposite the deontological views shared by Kant are consequentialist positions. Central to this perspective is the allusions made by pleasure theories among some of which are hedonism and utilitarianism which can be referred to as modern hedonism. The primacy of pleasure in human action was central in Cyrenaic hedonism founded by aristippus of cyrene. The dominant thought which they proclaimed was the socratic belief that virtue is a sine qua non of happiness. Here, they equated pleasure with happiness and concluded that pleasure is man's highest attainable good (Sahakian..).it is important to note that cyrenaics held a quantitative view of hedonism. This means that they conceived of pleasure as being of a single kind; physical satisfaction and as a 
result it could not be designated as either inferior or superior sice they only differ in intensity or duration. The corollary analysis is that pleasure is not intrinsically evil, however, the laws and customs of a society designates it as being good or evil. Further, they conceived of two kinds of emotion; emotion of pleasure which consisted of the sensation of gentle motion and the emotion of pain which is a violent motion. Pleasure here could be equated to the pleasant feeling of a hungry person who has immediately satisfied his appetite.

Utilitarianism in British philosophy can be traced as far back as William Paley (1743-1805). Jeremy Bentham (1748-1832) is, however, considered the father of modern Utilitarianism in the proper sense. He is considered as such because he was responsible for making the utilitarian principle serve as the basis for a unified and comprehensive ethical system that applies, at least in theory, to every area of human life. Bentham (1789) begins the ethical part of his work,The Principles of Morals and Legislation(1789)with a straight forward statement that, "Nature has placed mankind under the governance of two sovereign masters, pain and pleasure" (Bentham, 1789). By this anything that seems good must either be pleasurable or thought to be a means to pleasure or to the avoidance of pain. Conversely, anything that seems bad must either be directly painful or thought to be a means to pain or to the deprivation of pleasure. From this proposition, Bentham further argues that the words 'right' and 'wrong' can only be meaningful if they are used in accordance with the utilitarian principle, so that whatever increases the net surplus of pleasure over pain is right and whatever decreases it is wrong (Bentham, 1789). To him we must calculate the amount of pleasure to be derived from an action before we act. In this way, we use the hedonistic calculus to consider the nature of certain pleasures and pains by looking at their intensity, how long they last or their duration, purity, propinquity, fecundity and whether they tend to give rise to further feelings of the same kind.

It is possible to think that Bentham did not really aim at propounding a theory that was to explain or justify ordinary moral view but rather, develop a system that was to reform ordinary moral behaviour. The striking fact about Bentham's theory is that, instead of deriving the concept of human nature from the ultimate end of human activity, he draws the ideas of human ends from the real 
Kwo Kwegya: Eclectic Approach to the Categorical ...

nature of man.For Bentham, utility is the normative link between our conception of humans and the desired end of human actions directed towards the happiness of all those directly or indirectly affected by the action. Thus, the principle of utility demands that an action is right or wrong according to the tendency of the action to advance or thwart the production of the happiness of the party whose interest is in question, be it individual or collective.

Bentham's position was criticised for being fit for the pigs, especially, when he reaffirmed that all pleasures are equal but only differ in quantity. In other words, a child's play is equal to reading poetry. Mill (1863), the leading proponent of the utilitarian theory after Bentham, in his work, Utilitarianism made several modifications to the theory, all aimed at establishing a broader view of what utilitarianism really stood for and also to make the theory less vulnerable to criticisms. We, however, note that Mill reaffirmed the basic tenet of utilitarianism as Bentham (1789) had outlined. He thus conceived that the creed which accepts as the foundation of morals, utility or the greatest happiness principle holds that actions are right in proportion as they tend to promote happiness, wrong as tend to produce the reverse of happiness. By happiness is intended pleasure and the absence of pain; by unhappiness, pain and the privation of pleasure (Mill, 1863).

Although his position is also based on the minimisation of happiness, which consists of pleasure and the absence of pain, he distinguishes between pleasures that are higher and/or lower in quality. Thus, he said that it is "better to be Socrates dissatisfied than a fool satisfied" (Mill, 1863). More so, Mill (1871) also sought to show that Utilitarianism is compatible with moral rules and principle relating to justice, honesty and truthfulness. This he did with the argument that moral agents should not attempt to calculate the pleasure to be derived before an action is taken. Instead, they should be guided by the fact that an action falls under a general principle, such as the principle tends to increase happiness (Mill, 1863). However, we may consider whether exceptions can be made but it might seem possible under very necessary and specific circumstances. 


\section{The Categorical Imperative}

The categorical imperative on a critical assessment is a command that addresses, controls and constrains our will. Here there are no 'ifs', one ought to do it, period (Omoregbe, 2004). This, according to Kant, is so because morality concerns how we ought to live and act. Thus to Kant;

...there is one imperative which directly commands

a certain conduct without making its condition some purpose to be reached by it.This imperative is categorical. It concerns not the material of the action and its intended result but the form and the principle from which it results. What is essentially good in it consists in the intention, the result being what it may. This imperative may be called the imperative of morality. (Kant, 1959: )

By this, a categorical imperative is unconditional and independent of anything, circumstances, goals or desires. It is for this reason that only a categorical imperative can be a universal and binding law; that is, a moral law valid for all rational beings at all times. Kant explains the categorical imperative with an assumption that a principle upon which a perfectly rational agent would act is also that upon which an imperfectly rational agent ought to act if he is tempted to do otherwise. It must be noted, here, that Kant's deontology is guided by a fundamental belief that everything in nature works according to rules and morally it is only rational beings that have the power to act in accordance with these principles or rules (Ozumba, 2002). As a result, the categorical imperative is one of such principles by which rational agents act. The categorical imperative is, therefore, an imperative of reason itself and is used for making other rules Kant calls maxims. This is similar to the Golden Rule which states that "Do unto others as you would have them do unto you" (Audi, 1996). The question of the Golden Rule, however, is not without problems. For instance, the rule would not be able to answer a question like; "Does everybody want to be done unto as you do unto yourself, however good or bad that action might be?"

The categorical imperative which emanates from the concept of duty also implies the absolute application of moral laws. 
Kwo Kwegya: Eclectic Approach to the Categorical ...

By this, a maxim which one wills that it can become a universal law does become absolute since that maxim becomes categorical. Also, many maxims which we think might be very beneficial at a certain stage in one's life would become self-defeating. It is obvious that telling lies, for instance, is sometimes very beneficial to humanity, in spite of its moral connotation. However, in the realm of Kantian ethics absolute rules and the strict adherence to duty some of these maxims would become unhelpful and morally empty. The maxim that "it is permissible to lie" when fully analyzed in Kantian ethics would be self-defeating since it is generally accepted that lying is wrong. More so, if this maxim was to become absolute, the idea of truthfulness will lose its value and people will lie to achieve whatever ends they want to.

This view of absolutely endorsing the wrongness of lies is not devoid of problems. A reflection on this question brings many examples to mind. A typical example is the case of the inquiring murderer who enters a house looking for a young lady running away from him. At this stage eye witnesses are left abase whether to tell the truth or lie about the whereabouts of the lady. Such an example indeed shows the difficulty in the universalisability and even possible non-universalisability of certain maxims. This is because the duty not to lie seriously comes into conflict with the duty to save (an innocent) life. On the basis of this example, we are left biting our nails since we do not know whether a different maxim might better be universalisable.

We, so far, realize that being a moral agent, then, means guiding one's conduct by "universal laws", that is, moral rules that hold without exception in all circumstances. As such, we should only do those actions that conform to rules that we could will to be adopted universally. And so if we lie, we would be following the rule that "it is permissible to lie." This rule could however not be adopted universally because it would be self-defeating since people would stop believing one another and then it would do no good to lie. Therefore, we should not lie and the duty not to lie is, in this case, absolute, Kant reiterates.

However, some situations provide an example of when an exception is in order. Kantian thought indicates that we would be morally responsible for any bad consequences as a result of our lying. Suppose, however, that our telling the truth results in a 
Ogirisi: a new journal of African studies, vol. 14, 2018

morally reprehensible outcome? Here, Kant seems to suggest that we would be blameless. But how convincing is his response? In considering the duty not to lie as an absolute rule or maxim which would, of course, admit of no exceptions, we still would have to answer a question like, what is the wrongness in lying to save an innocent person's life?

With reference to the categorical imperative, Kant offers three formulations. The first is the Formula of Universal Law. This formula holds that, act only on that maxim through which you can at the same time will that it should become a universal law(Kant, 1959).Generally, a categorical imperative simply bids us to act in accordance with a universal law. In other words, we are to act on a principle which is valid for all rational beings and not merely on that which becomes valid when it is a means to a certain end, be it our own end or the desired end of others. Another way to understand this formula is that, moral imperatives require that the maxims be chosen as though they should hold as universal laws of nature (Paton, 1964). Thus, one interpretation of the first formulation is called the universalisability test which has five steps.

- The agent finds a maxim.

- The agent imagines a possible world in which everyone in a similar position follows that maxim.

- The agent decides whether there are contradictions or irrationalities as a result of following the maxim.

- If a contradiction or irrationality arises, acting on that maxim is not allowed.

- If there is no contradiction, then, acting on that maxim is permissible (Davidson, 1968)

The second formulation of the CI is the formula of the End-in-Itself. The formula holds that, act in such a way that you always treat humanity, whether in your own person or in the person of any other, never simply as a means, but always at the same time as an end (Kant, 1959). Here, the ends being referred to might either be subjective or objective ends. The subjective ends might be hypothetical imperatives; their adoption is at the individual's discretion. It may also be an objective end, that is, an end which 
Kwo Kwegya: Eclectic Approach to the Categorical ...

carries an unconditional value and which a rational agent would necessarily pursue. The principle here is, act with reference to every rational being so that it is an end in itself in your maxim.

The Formula of the Law of Nature is conceived as the third formulation. It states that, act as if the maxim of your action were to become through your will a universal law of nature (Kant, 1959). Primarily, a law of nature may be conceived as a law of cause and effect. However, as Paton (1964) explains, when Kant asks us to consider our maxims as if they were laws of nature, he treats these laws as teleological. Kant generally holds, according to this formula, that one becomes morally good when one acts on an impersonal principle valid for oneself and for others and not because one acts from passion or self-interest. This, Kant believes, is the essence of morality. He, however, thinks that if we wish to test the maxim of a proposed action, we must ask whether it would further a systematic harmony of purposes in the individual and in the human race, if the maxim is universally adopted (Ewing, 1976). So act that your will can regard itself at the same time as making universal law through its maxim (Kant, 1959), is referred to as the formula of Autonomy. The formula carries the import that the categorical imperative does not only bid us to merely follow a universal law, but to follow a universal law which we ourselves make as rational agents. Kant believes that this is the most important formulation of the supreme principle of morality since it leads to the idea of freedom. The implicit explanation is that human beings are not only bound to obey universal laws but that rational agents are the foundation of these laws.The last formulation for the CI is the formula of the Kingdom of Ends which also states that so act as if you were through your maxims a law-making member of a kingdom of ends (Kant, 1959). The formula means that since rational agents are all subject to universal laws which they themselves make, they constitute a kingdom and so far as these laws bid them to treat each other as ends in themselves, the kingdom so constituted is a kingdom of ends. The formula is therefore seen to have sprung directly from the formula of Autonomy.

Generally, Kant first introduced the idea that our actions possess moral worth when we do our duty for its own sake as something accepted by our common moral consciousness and, then, tried to show that it is an essential element of any rational morality. 
One may ask then, does our common moral consciousness really insist that there is no moral worth in any action done for any motive other than duty? If so, then we certainly will not praise the young man who plunges into the river to rescue a drowning child if we learned that he did it because he expected a handsome reward from the child's rich father. But can we legitimately say it has no moral worth because the young man had other intentions? And would we happily advocate that people emulate the gestures of the young man? It would be difficult to know at this point which inclination followed the other. Whether it is the drive to save an innocent drowning child or the drive of a reward.

Kant's deontological ethics seems to run counter with the thoughts of those who see benevolent or sympathetic feelings as constituting a moral base. But we think that even a cursory analysis would reveal that there is, more often than not, a thin line between sympathetic feeling to act and an act of duty. For instance, how would we be able to explain the judgment of a jury who give a minimum sentence to a pregnant woman for theft? One cannot argue that they have not performed their duties since their duty was to punish thieves, however they could have given a maximum sentence to the pregnant woman. One can at this point summarize the categorical imperative by saying that it is an imperative because it commands the will and it is categorical because it commands us to do something unconditionally, which is without regard to consequences or personal desires (Birsch, 2002). The justification for it is that it is an injunction based upon reason.

\section{Mill's Qualitative Pleasure}

Having been impressed by Bentham's utilitarian ideas, Mill (18061873), who was Bentham's intellectual successor, saw the need to clothe utilitarianism with certain idealistic characteristics in order to rescue it from its uncouth lapse into a "pig philosophy". It must be noted that Bentham's basic premise was that the good was pleasure, which was of single quality and calculable in quantitative terms (Bentham, 1879). Mill reasoned that, in this case, it would be difficult to distinguish between a rational and irrational being since Bentham's claim implies that as long as one is enjoying pleasure it does not matter what kind of pleasure it is. Mill, then, introduced the concept of qualitative hedonism. This is the theory that pleasure 
Kwo Kwegya: Eclectic Approach to the Categorical ...

differs in kind as well as quality (Mill, 1895). That is, there are pleasures that are high in quality but low in quantity or less intense. Also, there are quantitatively higher pleasures with low quality. In his explanation, Sahakian (1974) used this example, that comparing a ton of coal to an ounce of diamond; all things being equal, a ton of coal is less valuable than a tiny diamond, despite the fact that both are composed of carbon atoms. In showing the need for us to consider the quality of pleasure other than the quantity, he said;

The only true or definite rule of conduct or standard of morality is the greatest happiness, but there is needed first a philosophical estimate of happiness. Quality as well as quantity of happiness is to be considered; less of a higher kind is preferable to more of a lower. The test of quality is the preference given by those who are acquainted with both. Socrates would rather choose to be Socrates dissatisfied than to be a pig satisfied. The pig probably would not, but then the pig knows only one side of the question; Socrates knows both (Mill, 1895: ).

The view that Mill entertains, here, is that when it comes to deciding which pleasures are more valuable than the other, it is the hedonic expert who is in a best position to do that because he has adequate experience with both types of pleasures. The hedonic expert is someone who has attained the rational and experiential capacity of both qualitative and quantitative pleasures and is aware of the long and short-term effects of both. Such a person, according to Mill, knows that it is preferable to be a human being than to be an animal because, he knows there is an important qualitative pleasure in merely being a man which vastly outweighs all the physical pleasures afforded to animals. Thus, for Mill, a being of higher faculties requires more to make him happy, capable probably of more acute suffering and is certainly accessible to it at more points than one of an inferior type; but in spite of these liabilities he can never really wish to sink into what he feels to be a lower grade of existence (Mill, 1895). 
With this further explanation, Mill sought to strengthen the potency of utilitarianism as a viable and respectable moral theory. It must be noted that Mill's claim seems to be comparable to that of Bentham, who argues that when a person is experiencing pleasure, it is difficult, if not impossible for him to deny that he, indeed, likes it (Bentham, 1879). In other words, while pleasure is being experienced, an individual must admit that he is in fact enjoying it. Mill in his claim also said: “... I apprehend, the sole evidence that it is possible to produce anything is desirable is that people do actually desire it" (Mill, 1895: ). This means that something is desirable merely on the grounds that it is capable of stimulating desire.Again, Mill raises several legitimate questions in his analysis. For instance, what is the source of the obligation of utilitarian morality? (Mill, 1895). He adds that pleasure is to be gained and pains to be avoided by the agent who aims at general happiness. Also, he lays special stress on a sanction which Bentham omitted to take note; the 'feeling of unity with his fellow-creatures, which makes a natural want of an individual of properly cultivated that his aims should be in harmony' (Mill, 1971: ). This feeling, according to Mill, in most individuals is much inferior in strength to their selfish feelings, but it presents itself to the minds of those who have it as an attribute which it would not be well for them to be without and this conviction is what Mill sees as the ultimate sanction of the greatest happiness morality (Sidgwick, 1967).

Mill's utilitarian thought is generally seen as a modification of Bentham's ideas. However, it has also been through much scrutiny and criticisms, especially the claim that pleasure alone is good and the further distinction that some pleasures are better pursued than others. Some moral philosophers like Urmson (1967) think that many of the critics of Mill actually do not understand him very well. According to Urmson, the general position of Mill is that, an action is justified as being right by showing that it is in accord with some moral rule. Also, a moral rule is shown to be correct by showing that the recognition of that rule promotes the ultimate end.

We realize from Mill's account that pleasure is always good for its own sake, thus, he refers to it as an 'ultimate principle'. To him, all men call something good because it is pleasant or conducive to pleasure and, thus, the only thing that men universally desire is 
Kwo Kwegya: Eclectic Approach to the Categorical ...

pleasure. Mill makes two observations that sparked controversy in his explanation of his version of utilitarianism. First of all, he declared that pleasure and human happiness are one and the same thing. That is, to say that a man is happy is to say that he is experiencing pleasure and to say that he is unhappy is to say that he is experiencing pain (Mill, 1895).Secondly, Mill claims that pleasure is good no matter whose pleasure it is. That is your neighbour's pleasure has precisely the same value as the pleasure of your own. Thus, if pleasure is good by its very nature, then, its goodness does not depend on where it is or by whom it is experienced. This view influenced him in his assertion that if pleasure is alone good in itself, then, it is every man's duty to maximise it and to minimise pain. An analysis of moral conduct is not complete when the motive for which an action is done is not taken into consideration. In fact, we sometimes bestow praise or blame on an individual based on the motive from which he acted. Thus, we are inclined to consider not what a person has done, but, what moved him to do what he did. Kant, for instance, played down the idea of looking at the consequences of an action. He was concerned with the motive behind the action. To him, so far as an individual's motive for a particular action is that of a dutiful motive, that action carries a moral worth. An action which is not promoted by a sense of duty is, however, not qualified as moral.

Furthermore, in dealing with the quality of pleasure, Mill had to respond to a criticism levelled against the Epicureans. It states that to assert that we should try to increase the total amount of pleasure to the maximum level seems to suggest that we should convert the whole world into an amusement park, disregarding all those fruits of civilized life that men prize and replace them with cheap and simple feeling of pleasure (Taylor, 1979). In their response, the Epicureans said that pleasure differ in many ways and as a result rejected the Cyrenaic way of life. Mill also in his response argues, as noted, that some pleasures are inherently better than others. He, even, proposed a test by which we can discriminate between these 'higher' and 'lower' pleasures. He proposes that when we consult the man who has experienced both 'higher' and 'lower' pleasures, we will find out that he prefers 'higher' pleasures (Mill, 1895). 
It, however, seems that Mill is giving primacy to the opposite view. He seems to entertain the view that man performs his duty in cases when his actions foster happiness in all who are affected by such actions. Thus, Mill gives primacy to consequences rather than the motive of duty. What we think is that when we say that a man's action is dutiful it must surely be a function of either his motive or the consequences of his actions and so the opposite views exercised by Kant and Mill can be reconciled. It was, therefore, not very relevant for Mill to spend time explaining that his utilitarianism incorporated the very concept of duty.It must be noted that Mill was motivated by a number of factors to offer a different dimension to utilitarianism. He was first of all moved by the various problems that Bentham's version posed hence his modifications. Secondly and more generally, he was also responding to the general ethical question as to whether universal ethical guidelines are possible. Thus, for Mill, utilitarianism is the most practicable and all-encompassing theory that fits well in moral deliberations. And so, he suggests in Utilitarianism that there is an ethical principle which could act as the foundation for universal ethical conduct. He thus stated:

The creed which accepts as the foundation of morals 'utility' or the 'greatest happiness principle' holds that actions are right in proportion as they tend to promote happiness; wrong as they tend to produce the reverse of happiness. By happiness is intended pleasure and the absence of pain; by unhappiness, pain and the privation of pleasure. To give a clear view of the moral standard set up by the theory, much more requires to be said; in particular, what thing it includes in the ideas of pain and pleasure and to what extent this is left an open question. (Mill, 1979: )

Mill agrees with Bentham that actions are good as they maximise pleasure and bad as they maximise the reverse of pleasure (Mill, 1895). One can unhesitatingly say that Mill believes that all actions are directed towards a particular end. By this end, there might be intermediate ends in actions that we take but the ultimate end in all actions is the pursuit of happiness and the avoidance of 
Kwo Kwegya: Eclectic Approach to the Categorical ...

pain. For instance, when we go to school, our earned certificates will help us to get good job, get money and have a fulfilled and satisfying life. Though we might encounter painful and unpleasant circumstances whilst going to school, the chain ultimately ends with pleasure and the avoidance of pain. On this note, we get the impression from Mill that the ultimate end of human beings is the maximisation of happiness. This is because Mill claims that when we talk of an end of human actions, that end must be desirable. The ultimate end of all actions is happiness and happiness is the only thing desirable as an end.

In proposing that actions are good in proportion as they tend to promote happiness and prevent pain, Mill implies that, on the one hand, as far as actions are concerned, the more we produce pleasure and the more we minimize pain the better the action becomes. On the other hand, Mill is concerned with the quality of the happiness being produced. What we generally get from Mill, here, is that what is good or a good ethical life is one that is rich in happiness - both quantity and quality. To test the quality of happiness, Mill believes that we can use human preferences. He further holds the view that, whenever we want to choose between both pleasures, the best decision rest with individuals who have had experiences with both higher and lower pleasures (they are better placed to choose) and they would choose higher pleasures over lower pleasures. Thus, he said, "... it is an unquestionable fact that those who are equally acquainted with and equally capable of appreciating and enjoying both do give a marked preference to the existence that employs their higher faculties" (Mill, 1979: ).The general inference made from Mill's thought is that the question of the summumbonum which constitutes the foundation of morality has been with us since the dawn of philosophy. This has accounted for the main problems in speculative thoughts, occupied the most gifted intellects and further divided them into opposing schools waging intellectual war against each other. The thematic claim of utilitarianism is the greatest happiness principle which holds that actions are right in proportion as they tend to maximize happiness and when it is geared towards the maximization of pain, such an action becomes wrong (Mill, 1971).

Humanely speaking, it is not only by the performance of an action that we consider as morally potent but also the consequences 
count as well. Let us note that even though Mill agreed with Bentham on the main utilitarian principle or the greatest happiness principle, he greatly differed from Bentham in the areas of prioritising pleasure. Here, Mill offered his qualitative modifications with the additional thought that pleasures being experienced by humans also differ in various ways. This view of Mill is important in establishing the moral worth of promoting higher pleasures which are largely intellectual over lower ones which are largely bodily pleasures, even though the latter promises to be intense. Also, Mill is of the view that the difficulty in achieving happiness in a positive way usually makes it justifiable for sentient beings to seek the minimisation of pain in all actions that we take. However, pain is acceptable when it has the tendency of leading to a greater good for all. It must also be noted that Mill equally responded to the criticism that individual agents cannot devote their primary time and energies making unending calculations of actions and their effects in order to perform them. In his response, Mill appealed to rule utilitarianism. Thus, he was of the view that we need to properly act in accordance with moral rules. Rule utilitarianism urges us to act in accordance with certain rules whose end result is the achievement of pleasure. Even though we act in accordance with moral rules, the value of each action we take is determined by reference to the principle of utility.

It must be noted that Kant sees the motivation of acting morally as the respect for the moral law. Mill shares a different view, to him, what motivates people to do the right thing or act morally can be attributed to moral sanctions - among other things. Here, Mill differed a bit from Bentham, he did not only appeal to moral sanctions and socially imposed sanctions like punishment and blame, but he reasoned further that there are internal sanctions like self-esteem, guilt and conscience which bid us to act morally. As social animals, it is easy to find out that every action that we take affect others as well, and though we might not be blamed or punished by society for performing certain actions, our sense of guilt and conscience are enough to propel us to do the right thing in so far as we are rational.Mill is undoubtedly a rule utilitarian by this version of utilitarianism that is, he alludes to the thought that there are rules that are geared towards the maximisation of happiness. Thus, rule utilitarianism stipulates that it is better to follow a rule 
Kwo Kwegya: Eclectic Approach to the Categorical ...

like promise keeping which might do more good than harm in terms of utility rather than allowing lying that might promote greater good.

\section{Towards Categorical Pleasure: Eclectic Approach}

With the passage of time, our ethical consideration has become more complex by the day. We believe that the best ethical theory is one which combines the strong points of different ethical views. And so, we think it is possible for an aspect of utilitarianism in this case, Mill's pleasure, to be fused into Kant's deontology, specifically the categorical imperative, to create an attractive synthesis for practical moral assessment.Kant's deontology recognises the categorical imperative as the fundamental principle that ought to underlie all actions. The imperative basically states that moral agents must act with the will that their actions can be raised to the level of a universal law. Our purpose here is to identify areas of possible harmony with pleasure. When we look at the categorical imperative and the various interpretations given by some moral philosophers, we realise that the views are diverse. For instance, Ebbinghaus (1954) believes that Kant's concept of the categorical imperative is so clear that it should hardly be misinterpreted. In this sense, moral philosophers who find it difficult to understand the requirement of the categorical imperative mostly concern themselves with the content of the categorical command and the inferences to be drawn from it. We believe this should be the best direction of assessment we can give the categorical command when we decide to look at the verbal definition of the categorical imperative the principle becomes simple but this will not bring out the moral import that the principle of the categorical imperative proposes to carry.

Kant's moral imperative is not the one which man acts upon under the condition of experience but rather it is a way of expressing the conditions under which a principle can have a categorical demand. In other words, Kant's principle does not emanate from our sensual experiences like pleasures or pain but it is a principle which directs us to how we ought to act. Ebbinghaus (1954) agrees that the categorical imperative is conceived as a fundamental principle which determines the laws that can be objectively valid for the decisions of our will. For instance, whenever we see ourselves as having a duty to perform certain action, we mean that we have a categorical command in mind or an objectively valid principle innate upon which we act. 
Further, Kant (1964) claims that acting in accordance with the categorical imperative is a performance of one's duty. Thus, the categorical imperative determines the concept of duty solely from its form. In other words, the imperative states what duty is and also the forms of duties we have. In this way, the categorical imperative is seen as failing to show how particular duties which it (categorical imperative) determines differ, at least materially, from one another. This becomes the formal character of the categorical imperative as a law of duty and it also provides the basis for a misinterpretation of the categorical imperative. Thus, the misinterpretation consists in the thought that defining duty in the formal sense necessarily confines moral philosophy rather than to state what the concept of duty is as regards its form and this makes it impossible to articulate particular duties that are materially different.

The idea we wish to state is that every concept of duty must begin by stating what duty consists in, that is, stating what the concept of duty is with regard to its form. For instance, if we say of a particular duty as consisting of producing pleasure for the individual alone, we have determined the concept of duty simply as regards its form. Even though we seem to agree that the focus of interpreting the categorical imperative must not necessarily be confined to its form, we think it is also the case that in determining the concept of duty, there is prudence in looking at its form, that is what that duty generally characterises. In this sense, the form of duty consists of abstract conception whereby duty is defined in abstraction without regard to its actual application in behaviour. This gives a clear, consistent and unequivocal view of the duty in question. This, we believe, Kant did in his ethics. Let us note that the formal characteristics and definition of duty also accounts for conditions under which that particular duty must be performed as well as the criteria by which such an action counts as duty. However, we believe that an account of what duty is does not only end at the formal definition. The material differences between duties are equally important as well.

Further analysis into Kant's thought, indeed, reveals that he was concerned with both the formal and the material conceptions of duty. The categorical imperative is also a material conception of duty whereby moral agents apply their formal conception of duty. It defines an action which is our duty and how we ought to act in 
Kwo Kwegya: Eclectic Approach to the Categorical ...

accordance with the requirements of duty. In other words, moral agents will have to apply Kant's formal conception of duty in determining the moral status of any given moral action such as enacting moral laws. In doing this, the key factor is whether or not the action passes the universalisability test. In this case, moral agents become legislators, not only for themselves but for others as well.

The categorical imperative seems vulnerable in some instances. For instance, there are instances when the imperative is abused and still holds valid. This sometimes calls for exception when acting in accordance with the categorical imperative. Hegel (1972) in his criticism of Kant claimed that whenever Kant deduced or tried to deduce particular kinds of duties, he found himself just going round in a vicious circle. The reason being that, in order to show a contradiction between a maxim and the possibility of willing that the maxim becomes a universal law, one has to always presuppose a possibility of a violation which rests on no one but the individual. That is, whenever a moral agent acts in a certain way, the maxim upon which he acts are purely from the innate goodwill and the justification of such a maxim is ultimately his own duty. What happens, then, is that, it becomes possible to put forward any kind of arbitrary conduct as a demand of duty. Mill (1895) agrees with this view when he said of Kant that, when Kant infers some precepts from actual duties of morality, he fails to show that there would be any contradiction in its adoption by all rational beings, especially in the case of immoral rules of conduct (Mill, 1895:10).

Furthermore, the categorical imperative has been scrutinised and challenged on the basis that moral requirements are not categorical but rather hypothetical. Let us note that Kant distinguished between categorical and hypothetical imperatives. The categorical imperative is a command that directs us on how we ought to act in order to be moral, the hypothetical is however a conditional imperative which is directed towards the achievement of certain ends. Kant holds that what is moral is a categorical command and they emanate from our motive of duty to perform an action with the will that the action passes the test of universal application. Hypothetical imperatives are, however, imperatives of feeling and desires which have a teleological tendency. Morality, in Kant's view, is not concerned with the consequences of actions since, more often 
than not, consequences are beyond the control of man (Kant, 1975). Simply put, Kant claims that moral requirements are categorical.

Philosophers such as Ayer (1946) criticized Kant by saying that when we say moral laws hold as categorical commands, we mean so because some individuals have their moral motivation emanating from God's displeasure or concern for being isolated and antagonized by society (Ayer, 1946). This view coheres with Broad's (1959) claim that some imperatives which we may call categorical, at least in the lives of some individuals, were once hypothetical and, then, gradually became categorical because of the strengths that individuals themselves gave it (Broad, 1959). As a result, some philosophers see nothing wrong with commands being hypothetical, provided such a command can be applied universally. The question that arises thereof is what principle counts as moral.

This question has attracted varied reactions from moral philosophers. Foot (1989) opines that moral requirements, contrary to Kant's views, are, in fact, hypothetical. For her, moral requirements are not independent of desires, for desires play an important role on the reason of an individual to act morally. She further observes that, "it is not evident that a man's desires could not give him reason to act honestly" (Foot, 1989:278). The difference between categorical and hypothetical imperatives are that categorical imperatives tell man what he ought to do, whatever his desires or interests whilst hypothetical tell man what he ought to do because he wants something as well as what he ought to do on grounds of self-interest (1989). This is a linguistic distinction of both commands, and her disagreement with Kant starts from here. She reasoned that if, indeed, moral requirements are categorical and as a result the linguistic distinction between categorical and hypothetical imperatives is potent, then, other rules such as rules of etiquette would be categorical since it is also independent of our desires and feelings.

In order to prove that rules like etiquette are not moral requirements, Kant must ascribe categorical imperatives special dignity and necessity which the mere linguistic distinction cannot capture. In other words, Foot observes, the claim that moral requirements are categorical needs additional proof to properly distinguish it from other rules, by which claim it must be able to, in fact, prove that moral requirements are independent of desires and 
Kwo Kwegya: Eclectic Approach to the Categorical ...

feelings. These views are also shared by Dreier (1997) in his observation that moral requirements are hypothetical. This is so because moral requirements are not independent of desires and so if the characterisation of categorical imperative is independent of desires, then, moral requirements are not categorical. He further opines that "A categorical imperative is one that each person has reason to follow, no matter what her desires" (Dreier, 1997, 96). And so "the only sort of reasons are instrumental reasons and this means that moral reasons are not categorical, they depend for their compelling force on contingent desires" $(1997,87)$.

We, thus, realise that there are times when there do not seem to be any problem in saying that we behave morally because we feel in a certain way, since it sometimes becomes natural because of our psychological way of learning what is moral. As a result of some of these concerns, Foot (1989) argues that we normally act on what is moral, not because we seem to be obliged by some reasons that are categorical but because we are taught to act morally and we want to promote the good of others. For categorical reasons are devoid of desires and we sometimes act morally based on feeling. For instance, a man who publicly declares that he is performing his duties to his children simply because it is his duty and not for any love or affection that he has towards his children would certainly not be liked by, even, his children, even though he is doing what is morally required of him. However, when he talks of the fact that he is looking after his children because of the love and affection he has for them, even, when he is not aware that it is his duty to do so, would certainly get the reciprocal love from his children. More so, one acts honestly because one is taught to be honest and it seems to also bring good to others. Kitcher (2004) seems to cast doubt on the view that we could attract moral principles from considerations of logic and rationality alone, as Kant proposes. In other words, it seems to be the case that Kant perceives morality as a matter of laws which are obligatorily applicable to all, a view captured by the concept of the categorical imperative. By this, morality is a matter of laws that holds universal application. It in fact seems to hold, as Kitcher observes, that Kant might have inherited such an idea from the natural law tradition where all human beings were equally "God's children." (Kitcher, 2004:578). We note, here, that the universal applicability of moral laws is a necessity in moral deliberations. The 
other side of the issue is that moral laws do not always hold universal acceptance and that even when they do, they do not have universal application. It therefore becomes prudent to allow for exception since there are occasions when a moral law may be practicable in one instance but may not in another instance. This does not deny the fact that acting in accordance with what is moral must necessarily be obligatory at all times. Kant's view that we are mostly distracted and influenced by other factors from acting on what counts as moral attests to the reason why it becomes obligatory to act, at least, most times in accordance with the moral law.

Our argument then seems to gain support from Dewey (1944) that when we consider Kant's deontology, it would be possible for any tyrant to supply an explanation by telling those in his power that what duty requires of them is their unconditional obedience and acceptance of his maxims. The effect is that if the will of the tyrant himself is to satisfy the principle of the categorical imperative, then, his subject must follow him in every possible exercise of their will. Ebbinghaus (1954), however, thinks that it is a misinterpretation of Kant since, for him, it is not possible to subject themselves under such a tyrant except when their own will determines them to this subjection. We see some difficulty in such a situation as to how we can have a universally and objective moral principle as Kant sets out to achieve. This is because there might be instances when someone might persuade another to act by his maxims means that ultimately, everyone will act the way he/she deems fit or in accordance with his maxims. The effect will be that society will lack cohesive principles. Also, it seems difficult whether Kant's idea of duty for duty sake, when we act with the motive of duty, including duty to obey those in authority, will allow one to act in accordance with one's own maxims when he is obliged to act by the maxims of a tyrant.

It is, however, important to note that man generally is a social animal. In all, our actions sometimes have effects on other people. Thus, Kant, in fact, did not disagree with this view and this is evident in his idea of a maxim passing the universalisability test. In being socially connected it also behoves on us to ensure that our actions carry positive effects on others. As a result, whether moral agents will follow their maxims or the maxim of others, it is generally accepted that what is moral also carries with it a tag that it 
Kwo Kwegya: Eclectic Approach to the Categorical ...

should also promote the happiness of others as well. And so Ebbinghaus even observed;

I do will my own happiness ... I can, secondly, will the happiness of others. But in the third place, in willing my own happiness, I also will on the principle that others should will my happiness. Now if on my side I do not will the happiness of others, I cannot will that my maxim should be acted on by others and consequently I cannot will that it should be a law. Hence, if the categorical imperative is valid, there follows from it as a definite command of duty that I must include within my end of happiness, the happiness of others (Ebbinghaus, 1954:108).

What we have done is to analyse the categorical imperative in the light of some of the concerns raised by some philosophers about the acceptability of the theory. The import is to assess the strength of the imperative in order to create the harmony we want to achieve. With the criticisms and analysis raised the categorical imperative basically puts moral responsibility in the hands of the individual. Moral agents act with the full responsibility and will that their action can benefit others. When the imperative advocates that we act on maxims that can be universalised it simply means that we do not legislate for ourselves but for everyone who would find him/herself in the particular situation one legislated. The difficulty is that not all moral agents can consistently act on maxims that are universalisable and always do so out of duty. Kant's view is that the categorical principle is known a priori and as such it takes purely rational moral agents to consistently act in accordance with the imperative. Thus, for moral agents to act in accordance with the categorical imperative without any problems, they must first of all, reach a certain rational height and be able to always act on their innate good will without any compulsion. However, moral agents who have not been able to work on their innate good will and as such 
reached the rational stage that Kant envisages will always find it difficult acting in accordance with the stipulations of the categorical imperative and so need to be commanded to. For such moral agents, acting on the categorical imperative is an absolute duty. By this, such individuals act on duty for the sake of duty. Kant's categorical imperative is still potent in directing us towards what is good and we think there are points where it merges with Mill's qualitative pleasure.

The thought of promoting the happiness of others when acting has also been an influence in the thought of utilitarians. In fact, happiness or pleasure as observed by utilitarians is the highest good and determines the way and manner that individual acts. A good act is one that promotes the happiness of the greatest number of people. Utilitarians mostly use pleasure and happiness interchangeably and we will not try any distinction even though there seem to be, at least, a difference in semantics. In his Principles of the Legislation of Morals, Bentham observed that pleasures are equal but only differ in quantity. This means that pleasures are calculable and moral agents ought to calculate the amount of pleasure an action will produce before acting. Bentham's view was heavily criticised for advocating that we act to maximise any pleasure at all without any distinction. This made it necessary for Mill to offer his distinction between qualitative or higher pleasure and quantitative or lower pleasure.

Mill observes that the ultimate end of utilitarianism is an existence which as far as possible exempts pain and is rich in enjoyment or happiness both in quantity and quality. Qualitative pleasure presupposes that there is always the need to look at the value of an action rather than the pleasantness of it. This is measured by the intellectual and rational development that the action will produce.When Mill proposes that pleasure can be conceived qualitatively, he means to say that mental pleasures are intrinsically more desirable and valuable than bodily pleasures (Mill, 1895). In other words, the superiority of qualitative pleasure far outweighs the quantitative measure of other compared pleasures. Mill termed qualitative pleasure as higher pleasure. Philosophers like Edwards (1979) suggest that Mill was influenced by the doctrine of Hutcheson who associated pleasure with knowledge and virtue and saw them as incomparably excellent and beatific than the most intense and lasting 
Kwo Kwegya: Eclectic Approach to the Categorical ...

enjoyments of the lower kinds (Hutcheson, 1969). We also conjecture that the thoughts of Plato in his Pheado might have also influenced Mill. This seems to be the case with the concept of eudaemonia in Greek classical philosophy (Aristotle, ).

Qualitative or higher pleasure involves pleasures that encompass intellectual, self-improvement and the rule of reason in enjoying happiness According to Mill, it should always be the case that if some pleasures are of high quality then they ought to be chosen over lower pleasures regardless of their respective quantities. Mill claims that we should choose higher pleasure no matter the situation we find ourselves in but was criticised as to what makes one pleasure valuable than the other and how we make such a choice. In other words, moral agents are being told to look at the quality of pleasure over quantity. In fact, in the analysis of Mill, rational agents ought to act in accordance with qualitative pleasure. But the question is what makes one pleasure more valuable or qualitative? To this, Mill observes that;

The test of quality... is the preference felt by those who, in their opportunities of experience, to which must be added their habits of self-consciousness and self-observation are best furnished with the means of comparison (Mill, 1895:16).

This means that it is not the case that all moral agents will choose higher pleasures over lower pleasures. Those who were able to see the difference are those who have had the opportunity to experience both pleasures and have attained a level of rational cognition which will allow them to make such a choice. It is worthy of note that Mill does not necessarily say that higher or qualitative pleasures are more pleasant than lower or quantitative pleasures or that mental pleasures are necessarily more pleasant than physical pleasures, but that it is the question of 'what makes one pleasure more valuable than another, merely as pleasure?' (Mill, 1895:14).Mill conceives of pleasure as not just any kind of satisfaction but rather the satisfaction that comes from exercising and developing the higher human faculties. This kind of happiness is found in the exercise of intelligence, imagination, skill and practice of moral virtue (Gibbs, 1986). The role that qualitative pleasure plays 
is to assign a central place to the development of our human powers, especially, self-improvement.

Again, Mill emphasises in his distinction that what distinguishes human beings from other animals is our mental power. With this power, we are able to discriminate between moral judgements, reasoning, imagination, aesthetic evaluation, etc. Also, moral agents are able to distinguish between higher and lower pleasures because of the mental power we possess. We note here that it is not everybody who is in the position to choose higher pleasures over lower pleasures. It is the one who is able to actively work on his mental capacity of discriminating between moral judgments. Thus a purely rational being is the one who will consistently choose higher pleasures over lower pleasures. According to Mill, one pleasure is generally more valuable than the other if competent judges prefer one over the other. In other words, the value of pleasure is determined not by its duration and intensity but by the preferences of competent judges. Mill conceives of a competent judge as one who has experienced both higher and lower pleasures and is consciously aware of the long and short term consequences and effects of both pleasures. The idea of competent judges has generated a lot of controversy among philosophers. But Mill states categorically that the competent judge must be acquainted with the different sorts of pleasure, must be equally susceptible to both classes of pleasures or is capable of enjoying the different kinds of pleasures and finally is able to make effective choices (Mill, 1895).

We realise that Mill's idea of competent judges are those who have attained a higher level of rational cognition and cannot be easily corrupted by sensory pleasures. It is not everyone who is able to become a competent judge and is as such able to consistently choose qualitative pleasure over quantitative pleasure, regardless of the duration of pleasure involved. Mill's thought rules out the criticism that the idea of competent judges are based on intellectual elitism because all moral agents have the capacity of attaining a rational level required to make a distinction between lower and higher pleasures.

Generally, we find the two concepts as having a merging point and thus become a point of harmony. The categorical imperative posits that we act with the will that our maxims can be universalised. Thus moral agents must consistently act with the 
Kwo Kwegya: Eclectic Approach to the Categorical ...

thought that those actions will hold universal applicability. The imperative gives absolute moral responsibility to the moral agent. It is realised that one has to reach a certain rational peak in order to be able to act consistently according to the principle of the categorical imperative. The categorical imperative also demands that moral agents think through their actions thoroughly before acting. The difficulty lies in how one is able to act in accordance with a consistently universalised maxim. The point is that it takes moral agents who have attained a level of rational cognition to do so. Kant thought of the good will as the basic good which is behind all actions, it is intrinsic but it is only the rational man who is able to act on the good will with the sense of duty. It means that the good will, which is the will behind our thoughts and actions that pass the universalibility test, is innate in every man, and acting according to the good will is acting in accordance with the requirements of the fundamental principle of morality - the categorical imperative. It, however, takes a certain intellectual and rational height to realise and be able to consistently act in accordance with the categorical imperative.

One major common denominator underlying the categorical imperative and qualitative pleasure is the unaided use of reason and intellectual capacity. Qualitative pleasure, in the way Mill conceives it, also demands moral responsibility from moral agents. The import is that one is morally underdeveloped when he/she chooses lower pleasure over higher pleasure. It is, for instance, if it becomes difficult to shun having fun at a beach to reading a literature book. The import is that moral agents must reach a high stage of rational decision making and control oneself before he/she can consistently choose qualitative pleasure over quantitative pleasure. In other words, it takes a moral agent who is self-conscious and has reached a high level of rational appreciation. This is the reason why Mill appeals to the competent judge. Conscious of the controversy this idea of competent judge has created, we think that the judge is the moral agent who has reached an appreciable level of self-control, rational cognition and intellectual understanding.

And so, both concepts demand that in order to achieve the moral height we ought to, there is the need to reach a rational level that allows us to appreciate and take moral decisions without any external promptings. The role of reason in moral action has been 
appreciated by both Kant and Mill. Kant sought to put morality on the foundation of pure reason where moral agents do not act on the basis of mere empirical factors. Kant sees morality as purely a priori and observes that it is the only means by which we can rid ethics of its problems. Mill did not disagree with Kant that reason must be allowed to play a major role in moral decision making. This is because it is not possible for moral agents who are not purely rational to choose qualitative pleasure over quantitative pleasure. Thus, even though, it might not be clear as Kant puts it, Mill's qualitative pleasure demands that we reach a certain rational and intellectual level before we can act.

It is the case that a human being with low level of mental faculty can easily gain satisfaction of his desires and be made fully content because he has low capacities of enjoyment. But he is not capable of the same level of happiness as a person of superior intelligence and character. Thus the higher being is more liable to pain, must suffer more discontent and will never be perfectly happy; yet his condition is happier and better (Gibbs, 1986). Acting in accordance with the categorical imperative is a duty and the same applies to Mill's higher pleasure. Moral agents must as a matter of duty choose qualitative pleasure if their action will have a moral worth. This integrates the ideal utilitarianism of Moore whereby he observes that there are some concepts that do not necessarily denote pleasure but are qualitative, for instance, friendship and aesthetic value. The categorical imperative can therefore be merged with qualitative pleasure to mean that it is categorical that we choose a qualitatively pleasurable action. In this way it becomes easier to universalise our maxims. Thus the good will also allow moral agents to act in accordance with the value of qualitative pleasures.

\section{Conclusion}

What we have done is create an opening of harmony for two pivotal concepts found in two theories that lie at the extreme ends of the moral continuum. The concept in utilitarianism that we sought to merge with Kant's deontology is, Mill's qualitative pleasure, With Kant's deontology, we look at the categorical imperative. We see these concepts as creating an opening for integration.Generally therefore, Kant's categorical imperative is summarised in one famous example. Consider the person who needs to borrow money and is 
Kwo Kwegya: Eclectic Approach to the Categorical ...

considering making a false promise to pay it back. The maxim that could be invoked is 'when in need of money, borrow it, promising to repay it, even though you do not intend to.' But when we generally apply the universality test to this maxim, it becomes clear that if everyone were to act in this way, the institution of promising itself would be undermined. The borrower would always make a promise, willing that there be no such thing as promises (Kant, 1959).

There are some principles in both Kant's deontology and utilitarianism that allow for a harmony between the two theories. Both theories observe the need for a moral action to be altruistic. The utilitarian argues that the good act is that which satisfies the greatest number of people. By this the welfare of the majority is taken into consideration. This view allows for the possibility that an action cannot always satisfy everybody but, at least, if the greatest number of people benefit from such an action, then, it is good. This view has been criticised for neglecting the minority. We, however, think that sometimes the greatest number does not necessarily mean a calculated number, but rather maximum applicability. Kant also shares an altruistic view since he believes that a moral law must be able to hold universal acceptance. As a result, any action that one takes must carry the will that the action becomes a universal law for anybody at anytime. In other words, the rational man is the one who legislates for all and so if an action A favours one but will not favour another when he is in the particular situation in which I am, then, I am not obliged to act in accordance with such an action.

The categorical imperative and qualitative pleasure both elicit from the moral agent a recognition of high moral standard and understanding. The basic underlying force is the motivation of duty as well as the intellectual height. Thus the hedonic expert proposed by Mill, is the one who has experiential and the leisure of comparison having known both quantitative and qualitative pleasures. 
Ogirisi: a new journal of African studies, vol. 14, 2018

The moral man in Kant's deontology is that person who has been able to universalise his actions without any adverse effect on society in practice. Such a person legislates from a subject maxim to an objective principle for which the categorical imperative becomes the framework. Thus the concept seems to run in different streams but converge to the same estuary.

\section{*Kow Kwegya Amissah Abraham}

Department of Classics and Philosophy

University of Cape Coast

Ghana.

kow.abraham@ucc.edu.gh 
Kwo Kwegya: Eclectic Approach to the Categorical ...

\section{References}

Aristotle, (1976). Ethics. (Thomson, trans.). London: Hazell Watson \&Viney Ltd.

Audi, R. (Ed.). (1996). The Cambridge dictionary of philosophy. New York: Cambridge University Press.

Ayer, A.J. (1946). Language, truth and logic. London: Pelican Books.

Bentham. J. (1789). An introduction to the principles of morals and legislation.In Jones and Sontag (Ed.), New York: McGrawHill Book Company.

Birsch, D. (2002). Philosophical issues: a brief introduction. New York:McGraw-Hill.

Broad, C.D. (1959). Kant. Cambridge: Cambridge University Press. Davidson, D. (1968). Actions, reasons and causes. In A.R. White (Ed.), The philosophy of action. Oxford: Oxford University Press.

Dewey, J. (1944). German philosophy and politics. Oxford: Oxford University Press.

Dreier, J. (1997). Human doubts about the practical justification of morality. In Cullity and Gaut, (Ed.), Ethics and practical reason. Oxford: Clarendon Press.

Ebbinghaus, J. (1954) Interpretation and misinterpretation of the categorical imperative. The Philosophical Quarterly. Vol.4. (No. 15).

Foot, P. (1989). Morality as a system of hypothetical imperatives. In Pojman (Ed.), Ethical theory.

Gibbs, B. (1986). Higher and lower pleasures. Philosophy. Vol. 61. (No. 235).

Hegel, (1972). The Tubingen essay of 1793. (H. S. Harris, Trans). Oxford: Oxford University Press.

Hutcheson, F. (1969).Collected works. New York: Hildesheim Olms. Kant, I. (1959). Groundwork of the metaphysics of morals. (T. K. Abbott, Trans.). London: Longmans, Green and Co. Ltd.

Kant, I. (1964). The metaphysical principles of virtue. (J. Ellington, Trans.). New York: The Boss - Merrill Company, Inc.

Kant, I. (1975). Philosophical correspondence 1759-1799. (J. Ellington, Trans.). Indianapolis: Hacket. 
Ogirisi: a new journal of African studies, vol. 14, 2018

Kitcher, P. (2004): Kant's argument for the categorical imperative. The philosophical quarterly, Vol LXXXI. (No. 52).

Mill, J.S. (1895). Utilitarianism. In Jones and Sontag (Ed.), New York: McGraw-Hill Book Company.

Mill, J.S. (1971). Essential works of John Stuart Mill. In Lerner (Ed.), New York: Bantam Bks.

Mill, J.S. (1979). Utilitarianism. Indianapolis: Hackett Publishing Company Ltd.

Moore, G.E. (1966). Ethics. London: Oxford University Press.

Omoregbe, J.I. (2004). Ethics: a systematic and historical study. Lagos: Joja Press Ltd.

Ozumba, G.O. (2002). A course text on ethics. Lagos: Obaroh and Ogbinaka Publishers Ltd.

Paton, H.J. (1964). The moral law. London: Hutchinson University Library.

Sahakian, W. (1974). Ethical philosophy. Oxford: Clarendon Press.

Sidgwick, H. (1967). Outlines of the history of ethics. New York: St Martin's Press.

Taylor, R. (1979). Good and evil: a new direction. New York: The Macmillan Company.

Urmson, J.O. (1967). The interpretation of the moral philosophy of J.S. Mill. In P. Foot (Ed.), Theories of ethics Oxford: Oxford University Press. 